\section{New England Public \\ Policy Center}

Director

Robert Tannenwald

\section{Deputy Director}

Darcy Rollins-Saas

\section{Staff \\ Heather Brome \\ Robert Clifford \\ Tom DeCoff \\ Michael O'Mara \\ Mary Pierotti \\ Alicia Sasser \\ Yael Shavit \\ Jennifer Weiner \\ Bo Zhao}

The New England Public Policy Center is dedicated to enhancing access to high-quality analysis on economic and public policy issues that affect the region.

For more information about the New England Public Policy Center, please visit: www.bos.frb.org/ economic/neppc/

The views expressed are the authors' and not necessarily those of the Federal Reserve Bank of Boston or the Federal Reserve System.

federal reserve BANK OF BOSTON ${ }^{T M}$

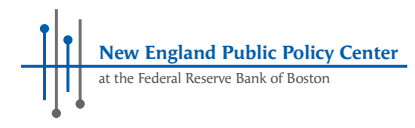

\title{
Revenue Forecasting Processes in New England
}

\author{
by Yael Shavit, Research Assistant
}

A key concern of state governments as they create their budgets is how much money they have to work with. The basis of a successful budget is a sound revenue estimate. In many states, the revenue forecast serves as a statutory constraint on spending. The forecasting process itself can be highly complicated, and differs among the states in important ways.

The current recession and economic uncertainty have created new challenges for state governments, which have seen actual revenues fall short of previous estimates and find themselves needing to cut their budgets. Most states have modified their revenue forecasting processes to address these extraordinary circumstances.

There is a dearth of readily accessible information on the processes that states use to create their revenue forecasts. To close that gap, this policy brief describes and compares the statutory processes in use in each New England state.

\section{Revenue forecasting overview}

Revenue forecasting is a mixture of science and art. At the heart of the process is the projection into the future of past relationships among underlying economic activities and revenue streams. The models that revenue forecasters use to estimate these relationships differ in their complexity and sophistication. Some models forecast future revenues from a number of sources at once, while others focus on individual sources.
The revenue forecasting processes used by New England states have key similarities. Most notably, the majority of states rely on a consensus process, which requires members of the legislature and the executive branch to agree jointly on a forecast. This contrasts with approaches that assign the bulk of decision-making authority to one branch of government. Almost all the New England states also revise forecasts more than once a year, and estimate revenue for multiple years beyond the budget year

One substantial difference among the states is the source of preliminary revenue forecasts. The process can be initiated by the state legislature, the executive branch, or by independent actors. States also differ on whether parties to that process must agree on economic projections before developing their initial revenue forecasts, and in what capacity nongovernmental actors participate in the process.

\section{The consensus process}

Consensus revenue forecasting is a collaborative process in which a group of people representing different perspectives-usually members of a committee or conferencejointly agree on an official revenue forecast. The most limited form of consensus forecasting includes representatives from the executive and legislative branches, while a broader consensus process also includes nongovernmental participants.

${ }^{1}$ This policy brief uses "revenue forecast" and "revenue estimate" interchangeably to refer to the revenue projections that serve as the basis for a state's budget. However, these terms are often used to describe different processes. "Revenue forecast" often refers to the revenue a state expects to generate over a given period, assuming no changes in the tax base or tax laws. A "revenue estimate" refers to a calculation of the expected changes in state revenue resulting from changes to existing tax law. 
Nearly every New England state uses a consensus revenue forecasting process, or a somewhat similar approach. In Maine, Rhode Island, Vermont, and Massachusetts, consensus forecasting is a statutory requirement.

Maine's consensus process is the broadest in New England. The state has two separate and independent consensus commissionsone responsible for producing an economic forecast, and the other responsible for producing a derivative revenue forecast. The membership of these commissions is determined by state statute.

Maine's Consensus Economic Forecasting Commission includes members appointed by the governor, the Senate, and the House of Representatives. The Revenue Forecasting Committee does not include any members of the legislature, but does include nonpartisan staff, the state budget officer, the state tax assessor, the director of the Office of Fiscal and Program Review, the state economist, and an economist from the University of Maine system. Unlike any other New England state, Maine's Revenue Forecasting Committee reaches agreement on the model used to calculate the revenue forecast and generates only one estimate, rather than debating a number of proposed estimates.

In Rhode Island, Vermont, and Massachusetts, consensus revenue forecasting groups consist of members of the legislative and executive branches. In Massachusetts, the revenue forecast is determined by the Senate and House Ways and Means committees and the executive secretary of administration and finance. This process has elements of a broader consensus system, as the principal estimates considered by the group come from the Department of Revenue and the Massachusetts Taxpayers Foundation, a nongovernmental organization. The group also hears testimony from a number of actors before deciding on a revenue estimate, including representatives from the Beacon Hill Institute, the Massachusetts Taxpayers Foundation, the Department of Revenue, the Federal Reserve Bank of Boston, and a professor from the University of Massachusetts in Boston. There is no statutory requirement specifying who must testify during this process.

Rhode Island's Revenue Estimating Conference includes the Senate fiscal advisor, the House fiscal advisor, and the state budget officer. These members propose their own revenue estimates, debate them, and then reach an official consensus projection for each revenue source.

In Vermont, the revenue forecast is approved by the Emergency Board, composed of the governor and the chairs of the House Committee on Appropriations, the House Committee on Ways and Means, the Senate Committee on Finance, and the Senate Committee on Appropriations. Before the Emergency Board meets, consulting economists for the executive and legislative branches prepare independent revenue forecasts, and thenattempt to reachaconsensus recommendation for board approval. Howev$\mathrm{er}$, in the rare event that a staff consensus is not reached, the Emergency Board hears from each economist and then determines the consensus estimate.

Neither Connecticut nor New Hampshire has a formal system for producing consensus revenue forecasts, but both states do require the executive and legislative branches to cooperate. Connecticut's legislature ultimately chooses an official revenue estimate. However, as part of the budget process, both the Office of Policy and Management (OPM) and the Office of Fiscal Analysis (OFA) submit initial revenue estimates. The OPM generates revenue forecasts used in the governor's biennial budget proposal and mid-biennium update. The OFA generates revenue forecasts used in the General Assembly's consideration of the budget. While the legislature tends to accept the OFA's projections, in practice it does so only when they are similar to the OPM figures. Otherwise, OPM and OFA reconcile their differences to arrive at forecasts used in the adopted budget.

In New Hampshire, the governor's budget includes an initial revenue estimate put together by the commissioner of Administrative Services. This estimate includes projections of tax revenue from the Department of Revenue and projections of individual revenue sources from specific agencies. During the legislative phase of the budget, the House and Senate rely on majority vote to develop the revenue forecast when determining the final budget. A New Hampshire Public Policy Institute report describes the state's revenue forecasting process as "a negotiated collaborative process between the legislative and executive branches." 


\section{Preparing economic projections}

Key inputs to these state revenue forecasts include national and state-level projections of economic variables such as unemployment, personal income growth, and inflation rates. Data from vendors-usually Global Insight, Moody's Economy.com, or both-inform the economic projections in every state.

In most states, different participants in the process hire different vendors, and there is no requirement that initial forecasts rely on the same economic assumptions. This is the case in New Hampshire, Vermont, and Connecticut. In Massachusetts, the Department of Revenue always provides a range of initial forecasts, with each relying on a different set of economic projections from different vendors. The department never mixes and matches these projections.

Maine and Rhode Island both require participants in the revenue forecasting process to reach a consensus economic forecast as a first step. In Rhode Island, the Revenue Forecasting Conference hears testimony from representatives of both Global Insight and Economy.com. After this testimony, conference members must reach consensus on 11 economic indicators, which they must then use in their preliminary revenue forecasts. As a result, all the preliminary forecasts rest on the same economic assumptions.

In Maine, the Revenue Forecasting Committee is required by statute to use economic projections agreed on by the Consensus Economic Forecasting Commission. Although members of both committees attend an annual retreat to review the past year and plan for future economic and revenue forecasting exercises, negotiation between the groups occurs rarely and only in extreme circumstances.

\section{Sources of preliminary forecasts}

While the process of choosing an official revenue estimate is collaborative in every New England state, the states differ substantially in who generates the preliminary revenue forecasts. In Connecticut, Rhode Island, and Vermont, initial revenue forecasts come directly from economists or fiscal advisors working for the legislature and the executive branch. In Connecticut, the forecasts come from the OPM and the OFA, while in Vermont a consulting economist for the Joint Fiscal Office and a consulting economist for the Agency of Administration propose the forecasts. Rhode Island is the only New England state where the Senate and the House each come up with an independent initial forecast. In addition to these two forecasts, Rhode Island's Budget Office proposes an initial forecast representing the executive branch.

In New Hampshire, the Governor recommends an initial revenue estimate developed by the commissioner of Administrative Services, with input from the Department of Revenue and other agencies. The House and Senate then repeat the revenue estimation process with agency input to develop their respective revenue estimates.

Unlike the other states, Massachusetts and Maine include independent actors in creating their initial forecasts. As noted, in Massachusetts, the legislature does not come up with an initial forecast but hears testimony from a number of groups. Maine has a unique system in which the members of the Revenue Forecasting Committee agree on a model and generate one revenue estimate.

\section{Involvement of academics}

Only Maine and Massachusetts formally engage academics in their revenue forecasting process. Connecticut and New Hampshire engage academics informally; Rhode Island and Vermont have little such engagement.

By statute, Maine's Revenue Forecasting Committee includes one economist from the University of Maine system. An economics professor from the University of Massachusetts in Boston regularly contributes testimony during Massachusetts' revenue forecasting process. Massachusetts has also recently sought to involve members of the Commonwealth's Council of Economic Advisors.

In New Hampshire, presentations by academics and economists inform the legislature during their revenue forecasting process. In Connecticut, informal conversations with academics or external regional actors help inform the revenue forecasting process. In Vermont, academics are not substantively involved, but forecasters may seek input from actors in key industries who have knowledge of revenue streams, such as economists associated with utilities, and managers of large firms.

\section{Transparency}

New England states divide evenly between those with highly public or transparent reve- 
nue forecasting processes and those with less public processes.

By statute, Rhode Island, Vermont, and Maine invite the public to observe all hearings and negotiations on revenue estimations. In New Hampshire, Connecticut, and Massachusetts, the public is invited to attend hearings in which testimony is offered or revenue forecasts are discussed, but some of the actual negotiations and resolutions do not occur publicly.

\section{Frequency of revenue forecasts}

States differ in how often they calculate their revenue estimates and the number of years they forecast. That frequency depends partly on the characteristics of each state's budget cycle. While Vermont, Rhode Island, and Massachusetts enact annual budgets, New Hampshire, Maine, and Connecticut enact two 12-month budgets every two years. Official revenue forecasts occur during the budget cycle to inform each state's budget, and re-forecasts (either formal or informal, depending on the state) occur throughout the year, to account for actual revenue receipts.

Rhode Island and Vermont develop revenue forecasts twice a year, and Massachusetts creates forecasts three times a year. Connecticut prepares official forecasts annually. Additionally, the OPM is statutorily required to release official monthly re-forecasts of revenues and expenditures, which the governor or General Assembly may act on. The OFA issues less formal revised forecasts three or four times each year.

In Maine, besides agreeing on a revenue forecast during even-numbered years, the Revenue Forecasting Committee must prepare official re-forecasts twice each year. In New Hampshire, revenue estimates are set in statute as part of the budget, and agencies or legislative committees offer informal updates when needed.

States also vary substantially in how far out they project their revenues. Maine's Revenue Forecasting Committee is charged with projecting revenue for the current fiscal biennium and two ensuing fiscal biennia. In setting its annual budget, Massachusetts requires revenue estimates for the ensuing fiscal year, while New Hampshire forecasts revenue for the two years of the biennial budget.

Connecticut's forecasts look at each fiscal year of the proposed biennial budget, and three ensuing fiscal years. Rhode Island's revenue forecasting conference formally estimates revenue for two fiscal years while performing economic forecasts for six fiscal years. The governor must also submit revenue and expenditure forecasts for four years beyond the budget year, and fiscal staffs usually prepare similar unofficial estimates for the Assembly to use in budget deliberations. Vermont projects revenue for the current and two ensuing fiscal years, while making less formal five-year projections.

\section{Dealing with today's economic challenges}

The current recession and economic uncertainty have seriously affected states' finances. New England states have all proposed substantial budget cuts in the last few months. Such economic conditions pose special problems for revenue forecasters, who face the daunting challenge of projecting state revenue under substantial uncertainty at a time when accurate forecasts are especially important.

New England forecasters have tackled this challenge in a number of ways. Unsurprisingly, most states in the region have chosen to revise their revenue forecasts with greater frequency. Connecticut and Maine have convened special meetings to address revenue shortfalls. In Maine, the Consensus Economic Forecasting Commission and the Revenue Forecasting Committee convened a rare joint meeting to agree on an estimate of the state's budget shortfalls.

Vermont instituted quarterly forecasts in January 2008, and will continue to prepare such forecasts while the revenue picture remains uncertain. Vermont, Rhode Island, and Massachusetts have also more explicitly differentiated between pessimistic and baseline forecasts when weighing preliminary revenue estimates. Massachusetts has sought greater involvement of external actors.

As more attention is focused on states' revenue forecasting processes, state governments may benefit from learning about the technical methodologies that other states use to estimate future revenues. Such methods likely vary based on states' tax structures, analytical capacity, and resources. The Center plans to conduct a comparison of the revenue forecasting methods used by the New England states in the future. 